\title{
BENTUK KOMUNIKASI SIMBOLIK TARI REJANG LILIT PADA UPACARA DEWA YAJNA DI DUSUN TANAH EMBET KABUPATEN LOMBOK BARAT
}

\author{
NI NYOMAN HARNIKA
}

\author{
Institut Agama Hindu Negeri Gde Pudja Mataram \\ e-mail : ninyomanharnika@gmail.com
}

\begin{abstract}
ABSTRAK
Kreativitas kesenian merupakan aktivitas nyolahang sastra dalam setiap pelaksanaan upacara yajña. Hal tersebut karena pertunjukan kesenian merupakan media penyampaian ajaran agama dan interaksi dengan orang lain. Masyarakat Dusun Tanah Embet mengimplementasikan komunikasi dalam tari rejang lilit melalui beragam gerakan tari sebagai simbol, merupakan bentuk komunikasi non verbal yang sarat makna.

Tujuan penelitian ini adalah menganalisis dan mendeskripsikan proses dan bentuk komunikasi simbolik tari rejang lilit. Pengumpulan data dilakukan dengan cara observasi, wawancara, dokumentasi. Analisi data yang digunakan analisis deskriptif

Hasil penelitian menunjukkan bahwa bentuk komunikasi simbolik tari rejang lilit dalam upacara dewa yajña di Dusun Tanah Embet adalah (1) komunikasi trancenden dalam bentuk verbal yaitu mantra dan dalam bentuk nonverbal banten; (2) komunikasi antar pribadi dalam bentuk nonverbal bunyi gong; (3). Komunikasi kelompok dalam bentuk verbal kata-kata atau bahasa pemangku dan dalam bentuk nonverbal gerakan tari rejang lilit.
\end{abstract}

Kata kunci : Komunikasi simbolik, Tari rejang lilit, Upacara dewa yajña, Bentuk

\section{ABSTRACT}

Arts creativities can be categorized as nyolahang sastra activity. That is because the performance of art is a medium for the delivery of religious teachings and interactions with others. The community of Tanah Embet Hamlet implements communication in rejang convolution dance through various dance movements as symbols, a form of non verbal communication that is full of meaning.

The purpose of this study is to analyze and describe the process and form of communication of the symbolic dance of twisted rejang dance. Data collection is done by means of observation, interviews, documentation. Data analysis used descriptive analysis

The results showed that the symbolic communication forms of the rejang lilit dance in the deity of Yajña in Tanah Embet were (1) transcendent communication in the verbal form of spells and in the form of nonverbal offerings; (2) interpersonal communication in the form of nonverbal gong sounds; (3). Group communication in the form of verbal words stakeholders or languages and in the form of non-verbal dance movements twisted rejang.

Keywords: Symbolic communication, Rejang lilit dance, Dewa Yajña ceremony, form

\section{PENDAHULUAN}

\section{Latar Belakang}

Manusia sebagai mahluk Tuhan yang sempurna pada hakekatnya masih membutuhkan pertolongan orang lain dalam berinteraksi. Begitu pula manusia dikatakan sebagai mahluk sosial yang tidak bisa hidup secara menyendiri, sehingga selalu hidup berkelompok dan membutuhkan orang lain sebagai teman dalam berinteraksi baik dalam kelompoknya maupun dalam masyarakat. Dalam agama Hindu manusia dikatakan sebagai mahluk Tuhan atau mahluk yang religiuskarena manusia adalah mahluk ciptaan Tuhan yang 
memiliki kelebihan dibandingkan mahluk yang lainnya, dalam artian hanya manusia yang mampu melaksanakan segala aktifitas keagamaan yaitu melaksanakan upacara yajña.

Begitu pula dalam ajaran agama Hindu terdapat lima upacara keagamaan yang disebut dengan Panca Yajña Adapun bagian-bagian dari Panca Yajña. Adapun bagian-bagian dari Panca Yajñameliputi : Dewa Yajña, Pitra Yajña, Manusa Yajña, Rsi Yajña, dan Butha Yajña. Berbagai aktivitas yang dilakukan umat Hindu tidak terlepas dari yajña tersebut, baik aktifitas di tempat suci (pura), maupun dilingkungan masyarakat dalam kehidupan sehari-hari. Tujuan utama dari pelaksanaan upacara yajña adalah menumbuhkan spiritual dalam rangka pengendalian diri menuju suatu pembebasan diri sehingga menuju suatu kedamaian. Yajña yang dilaksanakan umat Hindu selalu berlandaskan pada susastra suci Weda. Sehingga upacara yajña yang dilaksanakan dapat berjalan dengan lancar serta dapat memberikan makna terhadap kehidupan beragama.

Berdasarkan pernyataan di atas bahwa dalam melaksanakan berbagai upacara hendaknya umat Hindu tetap berpedoman pada Tri Kerangka Agama Hindu yang terdiri dari Tatwa, Susila, Upacara. Upacara sebagai salah satu bagian Tri Kerangka Agama Hindumemiliki tujuan mencapai kebahagiaan, kesejahteraan hidup serta kesucian lahir dan batin.Titib (2003:1) bahwa dalam memuja Tuhan yang acintya (tak terpikirkan) dalam segala kekuasaan umat Hindu menggunakan simbol-simbol berupa benda atau media yang dijadikan alat, spirit untuk memujanya. Simbol-simbol dalam agama Hindu sangat terkait dan tidak dapat dipisahkan dengan ajaran ketuhanaan (Teologi Hindu) karena simbol-simbol tersebut merupakan ekspresi untuk mendekatkan diri dengan Tuhan.

Tradisi umat Hindu untuk melaksanakan persembahyangan kepada Ida Sang Hyang Widhi umat Hindu pada umumnya menggunakan sarana banten. Selain banten atau sesajen sebagai pelengkap sarana dilengkapi pula dengan persembahan seni (tari dan tabuh). Seni merupakan aktualisasi nilai-nilai estetika dan religius yang tertuang dalam sastra Hindu.Dimana seni merupakan simbol kebenaran, kesucian, dan keindahan. Seni merupakan simbol pengajaran ajaran Weda melalui konsep pemahaman satyam (kebenaran), siwam (kesucian), dan sundaram(estetika/keindahan). Seni tari yang umum dipentaskan di pura sebagai tari sakral seperti tari Sanghyang, tari Rejang, tari Bebaris, Topeng, Barong, dan Rangda.

Salah satu seni yang sering ada dalam upacara Dewa Yadnya adalah seni tari.Tarian yang menjadi tari ssakral dalam mengiringi upacara Dewa Yadnya adalah tari rejang.Tari rejang pada umumnya ditarikan oleh para gadis dengan menggunakan pakainan putih kuning dengan hiasan janur dikepalanya.Namun berbeda dengan tari rejang lilit yang ditarikan dalam pelaksanaan upacara dewa yadnya di dusun Tanah Embet.Tari rejang lilit ini ditarikan dengan gerakan tarian yang sangat sederhana yaitu gerakannya diulang ulang mengikuti suara gamelan, dengan mengelilingi bale banten sebanyak tiga kali.Pakaian yang digunakanpun menggunakan pakaian adat ke Pura atau baju persembahyangan yang biasa dipakai ke Pura. Adapun penarinya/pregina adalah dari anak kecil berusia 5 tahun hingga oarang lanjut usia yang diperkirakan berusia 70 tahun. Tari rejang lilit adalah salah satu tari rejang yang dapat kita saksikan di Pura yang diamong disusun Tanah Embet.

Komunikasi dalam tari rejang lilit diimplementasikan melalui gerakan-gerakan tari rejang, sebagai simbol komunikasi umat dalam membangun oneness, yakni penyatuan dari mereka yang melakukan komunikasi . Dalam tari rejang lilit simbol-simbol komunikasi tersebut dilakukan oleh para pregina atau penari dari anak perempuan kecil berumur lima tahun hingga wanita tua yang masih mampu menari.

Beragam gerak dalam tari rejang lilit serta simbol-simbol yang terdapat di dalamnya memiliki makna tertentu.Dalam presfektif komunikasi simbol dan gerakan yang digunakan dalam tari rejang lilit merupakan bentuk komunikasi verbal dan nonverbal yang sarat makna. Dalam konteks inilah pentingnya dipahami tari rejang lilit yang dideskripsikan bentuk komunikasi simbolik yang ada di dalamnya.

\section{Rumusan Masalah}

Dari uraian di atas diajukan rumusan perrmasalahan adalah bagaimana bentuk komunikasi simbolik tari rejang lilit dalam upacara dewa yajña di Dusun Tanah Embet Kecamatan Batu Layar Kabupaten Lombok Barat?

\section{Tujuan Penelitian}

Penelitian ini bertujuan untuk mendeskripsikan dan menganalisis bentuk komunikasi simbolik tari rejang lilit dalam upacara dewa yajña di Dusun Tanah Embet Kecamatan Batu Layar Kabupaten Lombok Barat 


\section{METODE PENELITIAN}

\section{Lokasi Penelitian}

Penelitian ini dilaksanakan di pura-pura wilayah Dusun Tanah Embet, Kecamatan Batu Layar Kabupaten Lombok Barat, antara lain : Pura Melasa, Pura Batu Bolong, Pura Dalem Tanah Embet, Pura Paibon, Pura Maksan Tanah Embet.

\section{Jenis dan Sumber Data}

Jenis data yang digunakan adalah data kualitatif dan data kuantitatif yang bersumber dari data primer yaitu data yang diperoleh langsung dari hasil wawancara dengan narasumber atau informan yang dianggap berpotensi dalam memberikan informasi yang relevan dan sebenarnya di lapangan, dalam hal ini sumber primer diperoleh secara langsung dari informan dan aktivitas dalam tari rejang lilit (wawancara dan obsevasi), dan data sekunder adalah data yang diperoleh secara tidak langsung dari sumber utama, dapat dikatakan sebagai data pendukung data primer dari literatur dan dokumen berupa bahan bacaan, bahan pustaka, dan laporan-laporan penelitian

Penentuan informan dalam rencana penelitian ini dengan mengunakan teknik purposive, yaitu teknik penentuan sampel dengan pertimbangan tertentu Sugiyono (2005:78).Pertimbangan tertentu yang dimaksudkan adalah orang-orang yang memiliki wawasan, pengetahuan, pengalaman, dan memahami mengenai tari rejang lilit sehingga dapat memberikan informasi yang selengkap-lengkapnya, di samping informasi yang dijadikan subjek penelitian dapat dipertanggungjawabkan.

\section{Tehnik Pengumpulan Data}

Tehnik pengumpulan data yang digunakan dalam penelitian ini adalah sebagai berikut:1)/observasi partisipatif yaitu mengamati dan mengimbangi kegiatan-kegiatan informan dan mengamati proses tari rejang lilit yaitu gerakan-gerakan tari dan sarana yang digunakan dalam pementasan tari rejang lilit;2). wawancara, yanag tidak berstruktur, yaitu peneliti datang langsung ke lokasi penelitian melalui tanya jawab dengan mengajukan beberapa pertanyaan kepada informan terkait dengan komunikasi simbolik tari rejang lilit; 3). studi dokumendalam penelitian ini suatu cara yang digunakan untuk mengumpulkan data dalam penelitian, dengan cara mengumpulkan segala macam dokumen yang berkaitan dengan penelitian yang dilakukan dan mencatat dengan sistematis. Dokumen-dokumen yang diperlukan dalam penelitian ini adalah dokumen yang terkait dengan komunikasi simbol tari rejang lilit dalam upacara dewa yajña di Dusun Tanah Embet Kecamatan Batu Layar Kabupaten Lombok Barat.

\section{Tehnik Analisi Data}

Analisis data yang dilaksanakan dalam penelitian antara lain :1). reduksi data yaitu peneliti mengumpulkan data yang telah di uji kebenaranya yang berkaitan dengan komunikasi simbol tari rejang lilit dalam upacara dewa yajña di Dusun Tanah Embet Kecamatan Batu Layar Kabupaten Lombok Barat. Apabila dalam penelitian ini terdapat data yang belum terjawab oleh data yang telah terkumpul, maka peneliti akan menelusuri kembali di lapangan. 2). Penyajian Data (Display Data) langkah penyajian data dalam penelitian ini adalah dilakukan dengan menyajikan data yang diperoleh berkaitan dengan Semiotiks tari rejang lilit dalam pementasan pada upacara dewa yajña di Dusun Tanah Embet Kecamatan Batu Layar Kabupaten Lombok Barat; 3). Verifikasi Data untuk pengecekan keseluruhan dari data yang diterima atau tinjauan ulang terhadap catatan-catatan di lapangan dengan maksud untuk menguji kebenaran, kecocockan, dan validitas makna-makna yang muncul di lokasi penelitian mengenai komunikasi simbol tari rejang lilit yang di Pentaskan dalam upacara dewa yajña di Dusun Tanah Embet Kecamatan Batu Layar Kabupaten Lombok Barat.

\section{HASIL DAN PEMBAHASAN}

Dalam Kamus Besar Bahasa Indonesia, kata bentuk berarti : (1) lengkung, (2) gambaran, (3) rupa, (4) wujud, (5) sistem, susunan, (6) wujud yang ditampilkan, (7) susunan kalimat. Tim (1995:103-104). Hal yang sama juga diungkapkan Poerdarminta (1985:122) bentuk memiliki pengertian susunan, cara, rupa (ragam), 
atau wujud yang nampak. Sedangkan bentuk komunikasi menurut Mulyana (2006:72) dapat digolongkan dalam beberapa bentuk yaituu komunikasi intrapribadi (intrapersonal comunication), Komunikasi interpribadi (interpersonal communication), komunikasi kelompok (group communication), komunikasi publik (publik communication), dan komunikasi media massa (mass media communication).

Berdasarkan uraian di atas bahwa bentuk komunikasi simbolik adalah wujud komunikasi yang terjadi dari proses komunikasi atau penyampaian pesan dari komunikator dengan menggunakan lambang atau simbol. Menurut Riswandi (2009:6) komunikasi pada dasarnya merupakan tindakan yang dilakukan dengan menggunakan lambang-lambang.Lebih lanjut dikatakan bahwa lambang atau simbol adalah sesuatu yang digunakan untuk menunjukkan sesuatu lainnya berdasarkan kesepakatan sekelompok orang.Lambang meliputi kata-kata atau pesan verbal, prilaku non-verbal, dan objek yang maknanya disepakati bersama.

Bentuk komunikasi simbolik dalam penelitian ini adalah komunikasi dengan menggunakan simbol, dimana simbol tersebut telah disepakati bersama oleh sekelompok orang.Simbol yang dimaksud adalah berupa simbol-simbol yang terdapat dalam pementasan tari rejang lilit di Dusun Tanah Embet. Penggunaan simbol sebagai media komunikasi dalam pementasan tari rejang lilit adalah berupa penggunaan lambang atau simbol verbal dan non verbal yaitu proses pementasan tari rejang lilit, gerak-gerak yang terdapat dalam tari rejang lilit, dan bunyi gong sebagai pengiring tari rejang lilit. Penggunaan lambang-lambang verbal non verbal ini dimaksudkan untuk memperkuat makna pesan yang disampaikan.

Berdasarkan pemaparan mengenai proses pementasan tari rejang lilit maka dalam pementasan tari rejang lilit pada upacara dewa yajña dapat dapat ditemukan beberapa bentuk komunikasi simbolik, yaitu bentuk komunikasi transenden (trancenden communication), bentuk komunikasi antarpribadi (interpersonal communication) dan bentuk komunikasi kelompok (group communication) baik secara verbal maupun non verbal yang akan dijelaskan sebagai berikut:

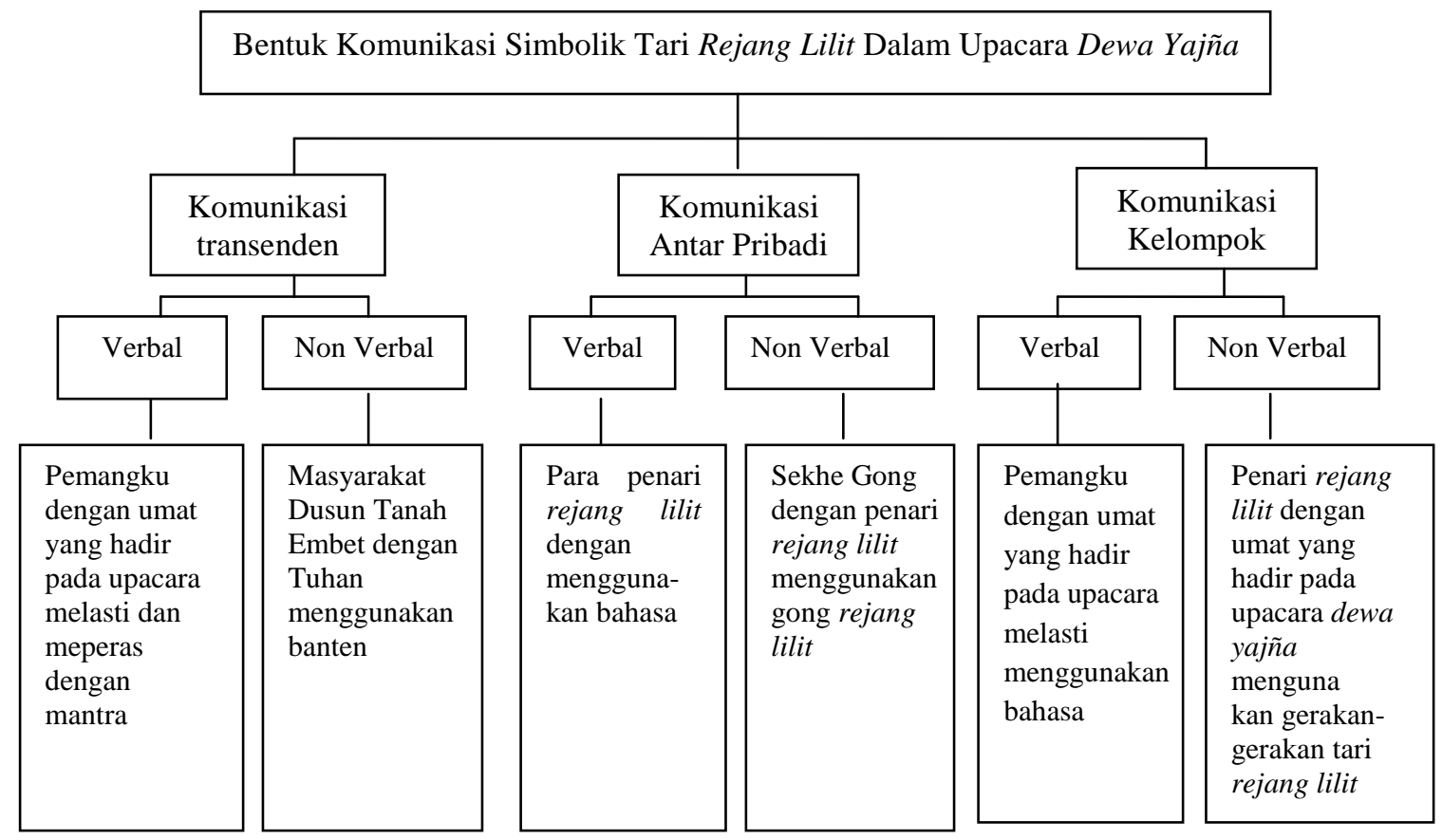

\section{Komunikasi Transenden}

Komunikasi transenden (transcendental comunicatiaon) adalah komunikasi antara manusia dengan Tuhan (Effendi, 2003:342). Dalam proses pementasan tari rejang lilit di Dusun Tanah Embet umat Hindu yang hadir, sudah melaksanakan komunikasi transenden (transcenden communication) melalui kekuatan adikodrati komunikasi transenden. Komunikasi transenden yang dilakukan dalam pementasan tari rejang lilit pada upacara dewa yajña dengan menggunakan simbol-simbol baik secara verbal maupun non verbal sebagai berikut:

Pertama komunikasi verbal dalam komunikasi transenden adalah komunikasi dengan menggunakan kata-kata sebagai simbol dalam setiap pementasan tari rejang lilit dalam upacara dewa yajña. Simbol verbal 
tersebut digunakan sebagai media untuk mengkomunikasikan pesan-pesan yang ingin disampaikan oleh komunikator kepada komunikan dengan bahasa sebagai media komunikasi.

Hal ini dipertegas oleh Dedy Mulyana (2005:73) yang menyatakan bahwa komunikasi verbal adalah semua jenis simbol yang menggunakan satu kata atau lebih. Hampir semua rangsangan wicara termasuk ke dalam kategori pesan verbal. Bahasa dapat didefinisikan sebagai seperangkat simbol dengan aturan untuk mengkombinasikan simbol-simbol tersebut, yang digunakan, dipahami suatu komunitas. Bahasa verbal adalah sarana utama untuk mengatakan pikiran, perasaan dan maksud kita. Komunikasi verbal menggunakan kata-kata yang mempresentasikan berbagai aspek realitas individual.

Dalam pementasan tari rejang lilit bentuk komunikasi verbal adalah mantra-mantra suci yang diucapkan oleh pemangku pada saat memimpin upacara melasti yang merupakan proses awal sebelum pementasan tari rejang lilit. Upacara melasti ini dilaksanakan sehari sebelum pelaksanaan upacara dewa yajña, upacara ini bertujuan untuk menyucikan diri sebelum melaksanakan upacara dewa yajña. Selain itu pengucapan mantra suci oleh pemangku adalah pada pelaksanaan upacara meperas. Upacara meperas ini dilaksanakan tiga hari kemudian setelah pelaksanaan upacara piodalan atau dewa yajña, dengan tujuan sebagai ungkapan rasa terima kasih atas keberhasilan menarikan rejang lilit dan mensukseskan pelaksanaan upacara piodalan atau dewa yajña.

Dalam komunikasi verbal ini terjadi proses komunikasi secara langsung. Komunikator yaitu pemangku, para penari rejang lilit, Sekhe gong, dan umat yang hadir saat upacara melasti dan meperas. Sementara komunikannya adalah tuhan. Sedangkan pesan yang disampaikan adalah berupa rasa bakti untuk memuja kebesaran Ida Sang Hyang Widhi Wasa. Adapun media yang digunakan adalah bahasa berupa mantra suci. Diketahui bahwa proses komunikasi adalah pemangku memimpin upacara melasti dan meperas dengan menggunakan mantra suci yang diikuti dengan persembahyangan bersama dalam upacara melasti dan natab banten peras dalam upacara meperas secara bersama-sama sebagai ungkapan syukur atas keberhasilan pementasan rejang lilit.

Komunikasi verbal dalam bentuk mantra-mantra suci yang diucapkan oleh pemangku yang memimpin jalanya upacara Melasti maupun Meperas menjadi pengantar persembahan umat Hindu kepada Ida Sang Hyang Widhi Wasa. Menurut Suarjaya (2010:78) mantra adalah aksara suci yang dipergunakan oleh sulinggih, pemangku dalam mengantarkan upacara keagamaan yang bermakna untuk menghidupkan kekuatan spiritual dalam upacara yajña. Saussure (1996:7) mengemukakan bahasa merupakan sederetan nama yang diterapkan terhadap konsep yang sudah ada sebelumnya dalam evolusi historis suatu bahasa konsep-konsep tersebut harus tetap stabil. Bahasa dapat diwuudkan dalam berbagai substansi tanpa mengubah sifat dasarnya sebagai sitem hubungan. Bahasa merupakan system tanda yang masing-masing terdiri atas dua segi, yaitu significant (segi bentuk) dan signijie (segi isi atau makna). Bunyi dapat dianggap sebagai bahasa apabila bunyi itu dapat digunakan untuk mengekspresikan atau mengkomunikasikan gagasan; jika tidak bunyi hanyalah sekedar bunyi. Dan untu mengkomunikasikan gagasan bunyi tersebut haruslah bagian dari system konvensi dan system tanda. Tanda tersebut adalah fakta sentral suatu bahasa.

Unsur-unsur bunyi digunakan dalam sebuah bahasa untuk membentuk 'ucapan suku kata' yang dibatasi oleh kemampuan alat bicara manusia dan kecerdasan membedakannya melalui pendengaran. Mantra disusun dengan menggunakan aksara-aksara tertentu, diatur sedemikian rupa sehingga menghasilkan suatu bentuk bunyi. Untuk menghasilkan pengaruh yang dikehendaki, mantra harus disuarakan dengan cara yang tetap sesuai dengan 'suara' atau ritma dan bunyi. Mantra mempunyai getaran atau suara tersendiri, karena itu apabila diterjemahkan ke dalam bahasa lain, mantra itu tidak memiliki warna yang sama. Mantra adalah daya kekuatan yang mendorong ucapan yang berkekuatan (yang buah dari padanya disebut siddhi) (Titib, 2000:442).

Mantra tidak bisa lepas dari aksara suci. Aksara suci dapat dibedakan menjadi tiga, yaitu tri aksara, dwi aksara, dan eka aksara. Tri aksara ini terdiri atas tiga huruf suci sebagai lambang pengakuan dan pemujaan terhadap Tuhan. Ini adalah simbol dalam bentuk ucapan, mantra atau doa. Ketiga huruf suci tersebut adalah $A$, $U$, dan $M$, yang di dalam pengucapan mantra dilafalkan sebagai Ang, Ung dan Mang atau AUM yang berdasrkan sandi suara $A U M$ ini berubah menjadi Aum atau Om. Dwi aksara terdiri atas dua huruf aksara yaitu Ang dan $A h$ adalah pranawa atau simbol kehidupan. Keduanya tidak dapat dipisahkan jika ingin hidup. Persatuan dari tri aksara AUM dan dwi aksara ANG dan $A H$ melahirkan suatu sloka suci untuk mantra yaitu Omkara, yang merupakan eka aksara Om. Pada setiap mantra yang diucapkan, dapat dipastikan mengandung salah satu atau lebih kata-kata suci (Nala, 2002:92).

Mantra adalah semua wahyu yang digubah dalam bentuk chanda. Asal mula terbentuknya mantra bersumber dari sabda atau suara yang dinyatakan sebagai sabdha Brahman. Semua mantra intinya adalah sabda yang merupakan perwujudan dari Brahman. Sabda membentuk semacam brahmanda tau bulatan telur yang maksudnya tidak lain merupakan perwujudan lingkaran gelombang suara yang terdiri atas dhwani, 
nada dan prana. Karena itulah maka apa yang disebut mantra adalah sthula sabda. Jadi mantra adalah komposisi aksara atau huruf-huruf yang diatur sedemikian rupa sehingga mempunyai kekuatan dan mampu memberikan akibat sebagaimana yang diharakan (Pudja, 1985:40).

Mantra juga dsebutkan unsur terpenting dalam upacara yajña. Mantra inilah yang akan dapat menyelesaikan suatu upacara yajña. Tidak ada upacara yajñayang disebut selesai kalau tidak dihantarkan dengan suatu mantra tertentu. Mantra ini berasal dari kata "man" dan "tra". Kata man artinya pikiran atau 'manah' Sedangkan kata tra artinya menyebrangkan. Jadi mantra adalah audio yang sakral dengan tujuan untuk menyebrangkan pikiran dari yang gelap menuju pikiran yang terang dan kuat (Wiana, 2001:2). Pikiran yang terang dan kuat itu akan mampu mengendalikan gerakan indra agar jangan melekat pada obyeknya. Karena pikiran yang dikuasai oleh indra melekat pada obyeknya maka pikiran akan menjadi gelap. Pikiran yang gelap itu akan menutup sinar suci Brahman menyampaikan karunianya. Pikiran yang gelap bias menjadi terang dengan jalan melakukan japa yaitu mengulang-ngulang mantra tertentu untuk menyebarkan pikiran yang gelap menuju pikiran yang semakin kuat dan terang (Suarjaya, 2010:80).

Kedua komunikasi nonverbal pada bentuk komunikasi transendendalam pementasan tari rejang lilit adalah komunikasi dengan menggunakan simbol banten. Dalam hal ini banten digunakan sebagai media komunikasi untuk menyampaikan pesan atau doa oleh seluru pihak-pihak yang terlibat dalam pementasan tari rejang lilit beserta umat yang hadir dalam upacara melasti dan upacara meperas sebagai komunikator kepada Tuhan sebagai wujud rasa bhakti.

Banten adalah persembahan suci yang dibuat dari sarana tertentu antara lain berupa bunga, buahbuahan, daun tertentu seperti sirih, dari makanan seperti nasi, lauk pauk, jajan. Sarana yang sangat penting lainnya adalah air dan api (Titib, 2000:80).

Komunikasi transenden dalam pementasan tari rejang lilit sesuai dengan teori tindakan komunikatif Jugran Habermas.Dimana dalam teori ini kehidupan komunikasi manusia dengan menggunakan simbol, teori interaksi komunikatif Habermas dapat menyingkap beberapa peluang bagi dialog antar manusia dengan tuhan dan manusia dengan manusia. Dialog yang terjadi diharapkan dapat membangun pemahaman melalui simbol yang digunakan.

Teori tindakan komunikatif Jugrer Haebermas yang menekan tindakan komunikatif lebih berorientasi untuk mencapai pemahaman bersama (konsesus). Harbermes mengatakan suatu intraksi adalah komunikasi jika pihak-pihak lain bisa mengkoordinasi rencana secara konsesus, kesepakatan yang dicapai pada setiap titik selalu dievaluasi dalam kaitannya dengan pengakuan intersubjektif atau klaim validitas. Dalam tindakan komunikatif pihak-pihak yang berbicara beranggapan bahwa mereka memaknai hal yang sama dengan ekspresi tertentu, bahwa apa yang mereka katakan akan bisa dipahami pendengar, bahwa proposisi mereka adalah benar, bahwa masing-masing bersifat tulus dan siap melaksanakan kewajiban demi pencapaian konsesus, dan bahwa mereka datang untuk memahami satu sama lain melalui proses dialog dimana mereka saling mendengarkan (Habermas, dalam Culler, 1985:34)

Dalam proses pementasan tari rejang lilit komunikasi transenden yang terjadi merupakan interaksi yang komunikatif, dimana komuunikator mengekpresikan emosi atau perasaannya. Ekspresi tersebut menimbulkan terjadinya dialog antara manusia dengan Tuhan yang diungkapkan melalui simbol matra yang diucapkan oleh pemangku dalam upacara melasti dan meperas. Selain itu simbol dalam komunikasi transenden disombolkan dalam wujud banten sebagai ungkapan rasa bakti terima kasih kepada Tuhan, sehingga dengan melakukan komunikasi dengan tuhan umat Hindu sera pihak-pihak yang terlibat dalam pementasan tari rejang lilit merasa lebih dekat dengan Tuhan.

\section{Komunikasi Antarpribadi}

Komunikasi antarpribadi (interpersonal communication) adalah komunikasi antara orang-orang secara tatap muka, yang memungkinkan setiap pesertanya menangkap reaksi orang lain secara langsung, baik secara verbal ataupun nonverbal. Bentuk khusus dari komunikasi antarpribadi ini adalah komuniksi diadik (dyadic communication) yang melibatkan hanya dua orang atau komunikasi triadic yang melibatkan tiga orang.Ciriciri komunikasi diadik adalah pihak-pihak yang berkomunikasi berada pada jarak yang dekat, pihak-pihak yang berkomunikasi mengirim pesan secara stimultan dan spontan baik secara verbal Mulyana (2005:73).

Dalam pementasan tari rejang lilit pada upacara dewa yajña terdapat komunikasi antarpribadi. Komunikasi antarpribadi ini terjadi komunikasi diadik yaitu pihak-pihak yang terlibat dalam pementasan tari rejang lilit baik itu para penari, sekhe gong, maupun pemangku berkomunikasi satu dengan yang lainnya secara tatap muka dan berada pada jarak yang berdekatan yaitu berada dalam satu arel pura pada pelaksaaan 
upacara dewa yajña. Komunikasi antarpribadi yang dilakukan dalam pementasan tari rejang lilit pada upacara dewa yajña dengan menggunakan simbol-simbol verbal dan nonverbal sebagai berikut:

Pertama komunikasi verbal, komunikasi verbal dalam komunikasi antarpribadi adalah komunikasi dengan menggunakan kata-kata sebagai simbol dalam setiap pementasan tari rejang lilit dalam upacara dewa yajña. Simbol verbal tersebut digunakan sebagai media untuk mengkomunikasikan pesan-pesan yang ingin disampaikan oleh komunikator kepada komunikan dengan bahasa sebagai media komunikasi.

Hal ini dipertegas oleh Dedy Mulyana (2005:73), bahwa komunikasi verbal adalah semua jenis simbol yang menggunakan satu kata atau lebih. Hampir semua rangsangan wicara termasuk ke dalam kategori pesan verbal. Bahasa dapat didefinisikan sebagai seperangkat simbol dengan aturan untuk mengkombinasikan simbol-simbol tersebut, yang digunakan, dipahami suatu komunitas. Bahasa verbal adalah sarana utama untuk mengatakan pikiran, perasaan dan maksud kita. Komunikasi verbal menggunakan kata-kata yang mempresentasikan berbagai aspek realitas individual.

Dalam pementasan tari rejang lilit bentuk komunikasi verbal adalah berupa bahasa antara sesama penari rejang lilit.Komunikasi ini terjadi pada saat pelaksanaan pementasan tari rejang lilit.Dimana dalam pementasan tari rejang lilit tersebut terjalin komunikasi secara diadik sesama penari rejang lilit. Proses komunikasi yang terjalin adalah proses komunikasi antara penari yang satu dengan penari yang lainnya. Dalam hal ini penari (kaum wanita yang lebih tua) bertindak sebagai komunikan dengan mengatakan ngiring sareng-sareng mekebah rejang lilit sementara itu komunikator adalah penari rejeng lilit lainnya dengan mengatakan inggih mekebah rejang lilit. Hal ini disebabkan karena antara penari yang satu dengan penari yang lainnya saling mengungkapkan bahasa berupa kata-kata yang sama. Adapun media yang digunakan adalah berupa kata-kata atau bahasa.Adapun pesan yang disampaikan adalah mengenai ungkapan rasa bahagia dan bersyukur karena dapat menarikan tari rejang lilit secara bersama-sama.

Kedua komunikasi komunikasi nonverbal pada komunikasi antarpribadi dengan proses komunikasi secara tatap muka. Proses komunikasi secara tatap muka, dalam proses komunikasi secara langsung dan berhadap-hadapan antara sekhe gong yang menbunyikan gamelan sebagai media yang diikuti oleh bunyi suara dari gong tersebut yang merupakan media kedua, kepada para komunikatornya. Para penari rejang lilit sebagai komunikannya yang menerima pesan dari komunikator (sekhe gong). Pesan yang ingin disampaikan adalah dengan berbunyinya gong tersebut maka tari rejang lilit mulai untuk ditariakan oleh para penari rejang lilit. Umpan balikknya berupa menarinya penari setelah mendengar bunyi gamelan tanpa ada yang mengkoordinir.

Komunikasi antarpribadi pada pementasan tari rejang lilit sesuaui dengan teori Interaksional simbolik, esensi dari interaksional simbolik adalah suatu aktifitas komunikasi yang merupakan ciri khas manusia dengan menggunakan simbol-simbol. Dalam komunikasi antarpribadi pada pementasan tari rejang lilit aktifitas komunikasi yang dilakukan kelompok atu pihak yang terlibat dalam pementasan tari rejang lilit baik secara verbal maupun nonverbal merupakan aktifitas komunikasi dengan menggunakan simbol suara gamelan (bentuk nonverbal) sebagai media komunikasi secara intrepersonal antara kelompok sekhe gong/gamelan dengan kelompok penari rejang lilit. Simbol yang digunakan sebagai media komunikasi telah disepakati sebelumnya oleh kedua pihak yang melakukan komunikasi.

\section{Komunikasi Kelompok}

Kelompok adalah sekumpulan orang yang mempunyai tujuan bersama yang berinteraksi satu sama lain untuk mencapai tujuan bersama, mengenal satu sama lain, dan memandang mereka sebagai bagian dari kelompok tersebut. Kelompok ini misalnya adalah keluarga, tetangga, kawan-kawan terdekat, kelompok diskusi, kelompok pemcahan masalah, atau suatu komite yang berapat untuk mengambil suatu keputusan. Dengan demikian komunikasi kelompok biasanya merujuk pada komunikasi yang dilakukan kelompok kecil tersebut (small-group communication). Komuniukasi kelompok dengan sendirinya melibatkan komunkasi antarpribadi, karena itu teori komunikasi antarpribadi berlaku bagi komunikasi kelompok (Mulyana, 2005:74).

Komunikasi kelompok dalam pementasan tari rejang lilit terdapat komunikasi secara verbal maupun komunikan non verbal, sebagai berikut :

Pertama komunikasi verbal, dalam komunikasi kelompok secara verbal dalam pementasan tari rejang lilit adalah adanya pelasanaan upacara melasti, dimana dalam pelaksanaan upacara melasti terjalin komunikasi antar kelompok pemangku dengan kelompok umat yang hadir pada saat pelaksanaan upacara Melasti. Proses komunikasi yang terjadi adalah proses komunikasi antara pemangku sebagai komunikator, umat yang hadir pada saat itu yang bertindak sebagai komunikannya. Adapun media yang digunakan adalah berupa kata-kata atau bahasa. Pesan yang ingin disampaikan adalah mengenai pelaksanaan upacara melasti 
dan doa kehadapan Ida Sang Hyang Widhi Wasa.Sementara itu timbal balik dari komunikasi tersebut adalah semua umat mengikuti pelasksanaan upacara melasti.

Bentuk verbal tersebut dalam upacara Melasti adalah pemangku berkomunikasi dengan menggunakan pengeras suara kepada kelompok umat yang melaksanakan upacara Melasti. Pesan yang disampaikan adalah dimulainya upacara melasti. Selain itu para pemangku memimpin pelaksanaan upacara dan doa sebagai pesan yang disampaiakan kepada Tuhan.

Hal ini sesuai dengan teori tindakan komunikatif Jugrer Haebermas yang menekankan tindakan komunikatif lebih berorientasi untuk mencapai pemahaman bersama (konsesus). Harbermes mengatakan suatu intraksi adalah komunikasi jika pihak-pihak lain bisa mengkoordinasi rencana secara konsesus, kesepakatan yang dicapai pada setiap titik selalu dievaluasi dalam kaitannya dengan pengakuan intersubjektif atau klaim validitas. Dalam tindakan komunikatif pihak-pihak yang berbicara beranggapan bahwa mereka memaknai hal yang sama dengan ekspresi tertentu, bahwa apa yang mereka katakan akan bisa dipahami pendengar, bahwa proposisi mereka adalah benar, bahwa masing-masing bersifat tulus dan siap melaksanakan kewajiban demi pencapaian konsesus, dan bahwa mereka datang untuk memahami satu sama lain melalui proses dialog dimana mereka saling mendengarkan (Habermas, dalam Culler, 1985:34).

Kedua komunikasi nonverbal proses komunikasi kelompok dalam pementasan tari rejang lilit adalah proses komunikasi yang terjadi antara para penari rejang lilit dengan masyarakat yang hadir dalam pelaksanaan upacara piodalan atau upacara yajña di dusun Tanah Embet. Pada komunikasi kelompok menggunakan simbol-simbol non verbal berupa gerakan tari sebagai media komunikasi umat.

Dalam proses komunikasi kelompok para penari rejang lilit sebagai komunikator atau pihak yang memberi informsi, sementara itu pemedek atau masyarakat yang hadir saat pelaksanaan upacara yajña sebagai komunikan atau pihak yang menerima pesan dari penari rejang lilit. Adapun pesan yang ingin disampaikan oleh komunikator adalah ekpresi rasa bakti masyarakat Dusun Tanah Embet kehadapan Ida Sang Hyang Widhi Wasa serta pelajaran akan nilai-nilai kehidupan terutama ajaran etika terhadap generasi muda. Media yang digunakan adalah gerakan-gerakan tari yang mengekspresikan jiwa penari dan merupakan simbol mudra yang sering digunakan sulinggih dalam memimpin upacara yajña.

Komunikasi kelompok dalam pementasan rejang lilit dalam upacara dewa yajña adalah penari rejang lilit (komunikator) menyampaikan pesan secara konyinyu kepada masyarakat yang hadir saat pelaksanaan upacara yajña. Adapun pesan yang disampaikan merupakan komunikasi simbolik tentang ekspresi seseorang dan nilai-nilai etika yang termasuk komunikasi non verbal yaitu gerakan-gerakan tari. Dalam komunikasi kelompok secara nonverbal ini para penari tidak dapat mengetahui secara pasti feetbeack dari komunikan, karena jumlah komunikannya sangat banyak.

Komunikasi kelompok yang dalam pementasan tari rejang lilit berdasarkan pada teori tindakan sosial Max weber, esensi teori ini adalah adanya tindakan sosial secara sadar melalui pikiran aktif menafsirkan pikiran orang. Dalam pementasan tari rejang lilit para penari mengekspresikan jiwa bakti dan pesan nilai kehidupan khususnya mengenai etika kepada masyarakat yang hadir saat pelaksanaan upacara yajña yang secara sadar ekspresi tersebut diungkapkan lewat gerakan tari rejang lilit.

\section{SIMPULAN DAN SARAN}

\section{Simpulan}

Berdasarkan hasil penelitian dapat disimpulkan sebagai berikut : Bentuk komunikasi simbolik dalam tari rejang lilit pada upacara dewa yajña di Dusun Tanah Embet Kecamatan Batulayar Kabupaten Lombok Barat adalah tergambar dari proses pementasan tari rejang lilit yaitu dari upacara melasti yang dilaksanakan sehari sebelum pementasan, tahapan pementasan tari rejang lilit pada upacara dewa yajña, dan upacara meperas yang dilaksanakan tiga hari setelah upacara dewa yajña. Dari keseluruhan proses pementasan tari rejang lilit terdapat bentuk komunikasi transenden, komunikasi antarpribadi dan komunikasi kelompok.

\section{Saran}

1. Bagi masyarakat Dusun Tanah Embet di harapkan untuk tetap mempertahankan keberadaan tari rejang lilit sebagai salah satu tari sakral, dan merupakan media komunikasi ajaran agama kepada generasi muda melalui kesenian khususnya seni tari. Juga adanya implementasi nilai-nilai yang terkandung dalam pementasan tari rejang lilit dalam kehidupan sehari-hari. 
2. PHDI dan Pemerintah khususnya dinas pariwisata agar menjaga kelestarian kesenian tradisional dan mempromosikan budaya tersebut.

\section{DAFTAR PUSTAKA}

Arikunto, Suharsimi. 2005. Prosedur Penelitian Suatu Pendekatan Prakeik. Rineka Cipta, Jakarta

Armayani, Ni Made Tausiria. 2012. Pementasan Tari Rejang Lilit Pada Upacara Dewa Yajna Di Pura Melasa Dususn Tanah Embet Kecamatan Batu Layar Kabupaten Lombok Barat. Denpasar : Tesis IHDN.

Bandem, I Made. 1983. Enslikopedia Tari Bali. Akademi Seni Tari Indonesia (Asti), Denpasar

Budiasih, Ni Wayan. 2008. Kebertahanan Tari Rejang Sutri Di Desa Batuan (Kajian Bentuk, Fungsi, dan Makna). Tesis IHDN, Denpasar

Bungin, Burhan. 2001. Metodelogi Penelitian Kualitatif. Raja Grafindo Persada. Jakarta

Culler Jonaathan. 1983. On Deconstruction Theory and Criticism after Structuralis. London : Routlage

Carey, James W. 1992. Communication as Culture: Essays on Media and Society. Newyork: Routledge.

Canggara, Hafied. 2010. Pengantar Ilmu Komunikasi. Jakarta : PT. RajaGrafindo Persada

Danim. 2002. Menjadi Peneliti Kualitatif. Pustaka Setia,Bandung

Dibia, I Wayan.2007. Perkembangan Seni Tari Di Bali. Proyek Sasana Budaya Bali Denpasar

Djelantik, A.A Made. 1990. Estetika Sebuah Pengantar.Masyarakat Seni Pertunjukan Bandung.

Enkins, Jenny dan Williams, Nick Vaughan. 2013. Teori-Teori Kritiis Menentang Pandangan Utama Studi Politik Internasional. Pustaka Pelajar. Yogyakarta

Kadri. 2011. Komunikasi Sosial Politik. Larispa, Mataram

Kembarawan, I Gusti Komang. 2005. Upacara Piodalan Di Pura Sawa Rangsa Kelurahan Dauhwaru Kecamatan Negara Kabupaten Jembrana (Bentuk, Fungsi, dan Makna). Denpasar : Tesis IHDN

Keramas, Dewa. Made, Tantera.2007. Metode Penelitian Kualitatif Dalam Ilmu Agama Dan Kebudayaan.: Paramitha, Surabaya

Margono, 2005.Metode Penelitian Pendidikan. PT. Rineka Cipta, Jakarta

Moleong, Lexy J. 2002. Metodelogi Penelitian Kualitatif. PT. Remaja Rosdakarya,Bandung

Mudjiono, Ricky dan Prihermono, Dicky. 2008. Kamus Umum Bahasa Indonesia Edisi Terbaru. Scientific Press, Tanggerang

Mulyana, Deddy dan Rakmat, Jalaludin. 2005.Komunikasi Antarbudaya Panduan Berkomunikasi Dengan Orang-Orang Berbeda Budaya. Remaja Rosdakarya. Bandung

Mulyana, Dedddy. 2008. Metodologi Penelitian Komunikasi. PT. Remaja Rosdakarya. Bandung

Mulyana, Dedddy. 2010. Metodologi Penelitian Kualitatif. PT. Remaja Rosdakarya, Bandung

Mulyana, Deddy. 2012. Ilmu Komunikasi Suatu Pengantar. : PT. Remaja Rosdakarya Bandung

Nawawi, Hadari. 2005. Metode Penelitian Bidang Sosial. Gajah Mada Univercity. Yogjakarta

Nala, I. G. N. 2002. Ayur Veda. Upada Sastra, Denpasar

Ngurah, I Gusti Made. Dkk. 2006.Buku Pendidikan Agama Hindu Untuk Perguruan Tinggi. Paramita. Surabaya

Puspita Sari, Ni Wayan. 2009. Studi Deskriftif Cerita Tantri (Nandhaka Harana) Dalam Membentuk Tembang Nilai-Nilai Pendidikan Etika. STAH Negeri Gde Pudja Mataram

Puyamadmaja, I.B. Oka. 1994. Panca Srada. Denpasar : Upada Sastra.

Raka, Ida Bagus. 2010. Pementasan Topeng Sidhakarya Dalam Upacara Pujawali Di Pura Desa Pakraman Sukasada Kecaamatan Sukasada Kabupaten Buleleng (Presfektif Pendidikan Agama Hindu). Tesis IHDN, Denpasar

Ridwan. 2006. Metode Dan Tehnik Penyusunan Tesis. Alfabetha,Bandung

Riswandi. 2009. Ilmu Komunikasi. Graha Ilmu, Yogyakarta

Riyanto, Yatim. 2005. Metode Penelitian Pendidikan. SIC. Surabaya

Selian, Rida Saufan. 2007. Analisis Semiotika Upacara "Ngerje” Kajian Estetika Tradisional Suku Gayo Di Dataran Tinggi Gayo Aceh Tengah.Universitas Negeri Semarang.

Suamba, Ida Bagus Putu. 1996. Yajna Basis Kehidupan (Sebuah Canang Sari). WARTA Hindu Dharma. Denpasar

Suarjaya, I W. dkk. 2010. Analisis Upacara Wana Kertih Di Pura Batukaru Desa Wongaye Gede. Paramita. Surabaya

Subagiasta, 2006.Tatwa Hindu Bagi Pandita Dan Pemangku. Paramita, Surabaya

Sudartha, Tjok Rai. 2007. Upadsa Tentang Ajaran-Ajaran Agama Hindu. Paramita, Surabaya. 
Sudirta, Ida Bagus dkk. 2007. Warta Hindu Dharma Agama Hindu. Ganesa Exact. Jakarta

Sumertini, Ni Wayan 2010. Tari Rejang Ngeraman Pada Upacara Ngusaba Di Desa Kendis Busung Biu Buleleng (Presfektif Bentuk Fungsi Dan Makna). IHDN Denpasar

Surayin, Ida Ayu Putu. 2005. Melangkah Kepersiapan Upakara-Upakara Yajna. Paramitha, Surabaya

Sugiyono. 2005. Memahami Penelitian Kualitatif. PT. Alfabda, Bandung

Sugiyono. 2008. Memahami Penelitian Kuantitatif, Kualitatif dan R\&B. .PT. Alfabda Bandung

Sugiyono. 2014. Metode Penelitian Pendidikan Pendekatan (Kuantitatif, Kualititatif, $R \& B$ ). Alfabeta. Bandung

Suparyogo dan Tabroni.2001. Metodelogi Penelitian Sosial Agama. PT Remaja Rosdakarya Bandung

Surada, I Made. 2007. Kamus Sansekertha-Indonesia. Paramitha,Surabaya

Swadiana, Oka. 2008. Barong Landung : Bernuansa Magis-Religius. Paramita, Surabaya.

Tim, Penyusun. 2005. Kamus Istilah Agama Hindu.Kantor Wilayah Agama Provinsi Bali Program Pengembang.an Lembaga- Lembaga Sosial Keagamaan Dan Lembaga Pendidikan Keagamaan Hindu Bali.

Titib , I Made. 2000. Veda Sabda Suci (Pedoman Praktis Kehidupan). Paramita Surabaya.

Titib. I Made. 2003. Theologi Dan Simbol-Simbol Dalam Agama Hindu. Paramitha, Surabaya

Triguna, Yudha Ida Bagus Gede. 2000. Perubahan Sosial Dan Kultur Masyarakat Hindu Bali, Widya Satya Dharma; Jurnal Kajian Hindu Budaya Dan Pembangunan. STIE Satya Dharma. Singaraja

Triguna, Yudha Ida Bagus Gede. 2003. Teori Tentang Simbol. Widya Dharma Denpasar

Wiyana, I Ketut. 2000. Arti Dan Fungsi SaranaPersembahyangan. Paramitha. Surabaya

Wahyuni, I Gusti Ayu.2012. Eksistensi Pementasan Barong Landung Di Banjar Kaliungu Kelod Kecamatan Denpasar Timur (Presfektif Pendididkan Agama Hindu).Tesis IHDN Denpasar.

Zoetmudler. J. P. 1995. Kamus Jawa Kuna Indonesia. PT. Gramedia Pusaka Utama, Jakarta 